\title{
Dispute erupts over Nazi research claims
}

[MUNICH] German science suffered less damage during the Nazi era than has been commonly assumed, despite the forced exodus of Jewish researchers and some of the worst medical crimes ever reported, according to a controversial new book.

Author Notker Hammerstein, a respected professor of history at the University of Frankfurt, argues that only a few non-Jewish scientists felt threatened by the Nazis, despite the regime's anti-intellectualism. His book on the history of Germany's research council, the Deutsche Forschungsgemeinschaft (DFG), The DFG under the Weimar Republic and the Third Reich, was commissioned by the DFG.

Although all Jewish scientists were expelled from their university chairs as one of the earliest acts of the Nazi regime, the quality of research did not fall significantly behind other countries, Hammerstein claims.

He argues that the academic mainstream in Germany adjusted rapidly to the new political environment. Academics were mainly concerned to save or promote their own careers and disciplines. They failed to recognize that 'normality' served an illegitimate totalitarian system, he concludes.

In 1933 the DFG was forced to abandon its founding principles, and peer review was replaced by favouritism and arbitrary decisions, says Hammerstein. When Rudolf Mentzel, a 36-year-old chemist, was made president in 1936, "the DFG basically stopped existing".

But, given the extraordinary circumstances, Hammerstein finds that a relatively normal academic life was maintained at universities. Although Hitler and the

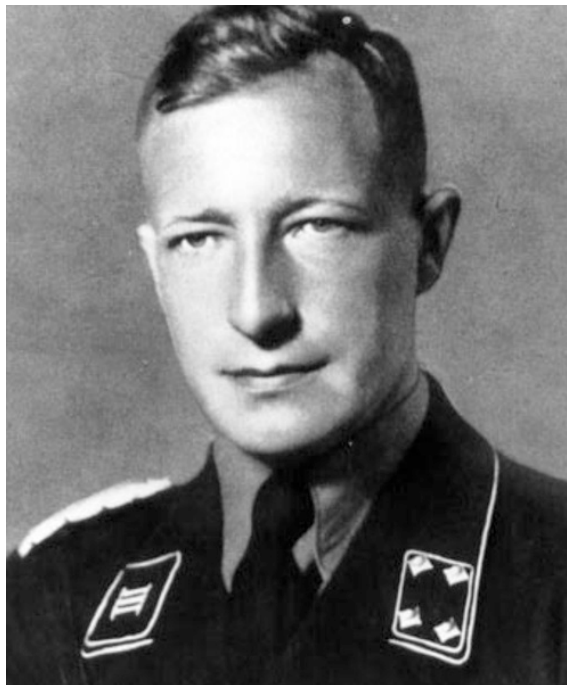

Rudolf Mentzel, whose presidency effectively wiped out Germany's research council.

Wehrmacht bosses had little interest in research, good science continued to get money. "Mentzel could not afford to fund only deadlosses and ideologists," says Hammerstein.

The ideological blindness of some scientists was extreme. Physicists such as Mentzel's predecessor Johannes Stark, and Philipp Lenard - both Nobel prizewinners and convinced anti-Semites — proclaimed a vaguely romantic "German Physics", which denied Einstein's "Jewish" theory of relativity.

Hammerstein's assessment has already been disputed. "The emigration of Jewish scientists led to a crucial decrease of Germany's intellectual competitiveness from which we still have not recovered complete- ly," says Ernst-Otto Fischer, who won the Nobel prize for chemistry in 1970.

Ernst Klee, author of several books about medicine in the Nazi era, says that Hammerstein has downplayed the DFG's involvement in medical war crimes. After 1940, funding applications were approved for research that included lethal experiments on humans. The DFG also supported what it called research into "the genetic disposition of the offspring of vagabonds, robbers and gypsies", but which historians believe was nothing more than a front for their extermination.

Hammerstein says that most DFG funds supported 'normal' research, unrelated to Nazi ideology, but Klee accuses him of simply trying to save the DFG embarrassment.

The book was commissioned in 1995 by former DFG president Wolfgang Frühwald to mark the research council's 75th anniversary. Frühwald said at the time that a critical assessment would be more appropriate than a "normal sort of celebration".

Wolfgang Schieder, a professor of history at the University of Cologne and an expert on fascism, defends Hammerstein. Sensitivity to Nazi issues, he says, often causes emotional reactions: "It is much easier to write about an eighteenth century problem."

The Max Planck Society (MPS), Germany's main non-university research organization, is also confronting its Nazi past. A five-year research programme by non-MPS scientists will examine the history of its pre-1945 predecessor, the Kaiser Wilhelm Society. It was launched this month with an international meeting in Berlin on science during the Nazi era.

QuirinSchiermeie

\section{Embattled French science agency says it is holding its own}

[PARIS] The Centre National de la Recherche Scientifique (CNRS) is by far the largest player in French research and its output is internationally competitive, it claims in a new study.

The French science agency is aiming to answer its critics: for over a year, it has been on the defensive following repeated attacks by the science minister Claude Allègre, whose reform plans would strengthen the universities - to the detriment of CNRS.

The agency is now becoming more assertive, bolstered by the recent ministry retreat on plans to impose reforms on it. Following a rebellion in the scientific community, the ministry ceded to CNRS demands for a national debate and a rethink of the reform plans in concert with the agency (see Nature 397, 463; 1999).

The study assesses the output and impact of papers with at least one CNRS author from 1986 to 1996, using journals indexed by ISI in the United States. It found that CNRS contributed to 52 per cent of the 370,000 French publications - those with at least one French address - published over the period in all 'hard' scientific disciplines.

This share rose to around 80 per cent in journals of physics, chemistry, astronomy and astrophysics. CNRS's share of French papers in biomedical journals was less than 20 per cent, but biomedical research is specifically catered for by another French agency, Inserm.

Papers with a CNRS author also had more impact than those from other French laboratories, according to the study. Its authors calculate that CNRS accounts for about 80 per cent of French impact in physics, chemistry, astronomy and astrophysics, two thirds in basic biology and 28 per cent in biomedical research.

At the international level, the average impact (in the two years following publication) of CNRS papers across all disciplines was - at around 1.2 equivalent to that of papers produced by all US scientists in ISI's Science Citation Index. CNRS papers made more impact than French papers overall, and more than those by German, British and Japanese authors.

Jacques Sevin, director of strategy and programmes at CNRS, says that the results are not a cause for complacency and improvements are still needed. But he argues that the study's conclusions provide an unequivocal response to outside pressure on CNRS to justify its performance.

France's share of the world's publications also rose from around 5 per cent to 7 per cent over the period surveyed. This is a respectable performance, say officials, given that the 'market share' of all nations is under pressure owing to sharp increases in the number of publications from emerging economies. 